\title{
Differential Expression and Functional Role of GATA-2, NF-E2, and GATA-1 in Normal Adult Hematopoiesis
}

\author{
C. Labbaye, M. Valtieri, T. Barberi, E. Meccia, B. Masella, E. Pelosi, G. L. Condorelli, U. Testa, and C. Peschle \\ Department of Hematology and Oncology, Istituto Superiore di Sanità, 00161 Rome, Italy; and Thomas Jefferson Cancer Institute, \\ Thomas Jefferson University, Philadelphia, Pennsylvania 19107-5541
}

\begin{abstract}
We have explored the expression of the transcription factors GATA-1, GATA-2, and NF-E2 in purified early hematopoietic progenitor cells (HPCs) induced to gradual unilineage erythroid or granulocytic differentiation by growth factor stimulus. GATA-2 mRNA and protein, already expressed in quiescent HPCs, is rapidly induced as early as $3 \mathrm{~h}$ after growth factor stimulus, but then declines in advanced erythroid and granulocytic differentiation and maturation. NFE2 and GATA-1 mRNAs and proteins, though not detected in quiescent HPCs, are gradually induced at 24-48 h in both erythroid and granulocytic culture. Beginning at late differentiation/early maturation stage, both transcription factors are further accumulated in the erythroid pathway, whereas they are suppressed in the granulopoietic series. Similarly, the erythropoietin receptor (EpR) is induced and sustainedly expressed during erythroid differentiation, although beginning at later times (i.e., day 5), whereas it is barely expressed in the granulopoietic pathway. In the first series of functional studies, HPCs were treated with antisense oligomers targeted to transcription factor mRNA: inhibition of GATA-2 expression caused a decreased number of both erythroid and granulocyte-monocytic clones, whereas inhibition of NF-E2 or GATA-1 expression induced a selective impairment of erythroid colony formation. In a second series of functional studies, HPCs treated with retinoic acid were induced to shift from erythroid to granulocytic differentiation (Labbaye et al. 1994. Blood. 83:651656); this was coupled with abrogation of GATA-1, NFE2, and EpR expression and conversely enhanced GATA-2 levels. These results indicate the expression and key role of GATA-2 in the early stages of HPC proliferation/differentiation. Conversely, NF-E2 and GATA-1 expression and function are apparently restricted to erythroid differentiation and maturation: their expression precedes that of the EpR, and their function may be in part mediated via the EpR. (J. Clin. Invest. 1995. 95:2346-2358.) Key words: hematopoiesis • transcription factor • progenitor cell
\end{abstract}

Address correspondence to C. Peschle, M.D., Thomas Jefferson Cancer Institute, Thomas Jefferson University, Bluemle Life Sciences Building, Room 528, 233 South 10th Street, Philadelphia, PA 19107-5541 Phone: 215-955-1763; FAX: 215-923-4153

Received for publication 12 August 1994 and in revised form 30 November 1994

J. Clin. Invest.

(c) The American Society for Clinical Investigation, Inc.

$0021-9738 / 95 / 05 / 2346 / 13 \quad \$ 2.00$

Volume 95, May 1995, 2346-2358

\section{Introduction}

Hematopoiesis is sustained by a pool of hematopoietic stem cells (HSCs) ${ }^{1}$ that can extensively self-renew and differentiate into progenitor cells (HPCs) (1). HPCs are committed to a specific lineage(s) and are functionally defined as colony- or burst-forming units (CFUs, BFUs): i.e., HPCs of the erythroid series (BFU-E, CFU-E), the megakaryocytic lineage (BFUMK, CFU-MK), the granulocyte-monocytic series (CFU-GM) and multipotent CFUs for the GM, erythroid, and megakaryocytic lineages (CFU-GEMM). HPCs in turn differentiate into morphologically recognizable precursors that mature to terminal elements circulating in peripheral blood.

Hematopoiesis is at least in part regulated by hematopoietic growth factors termed colony-stimulating factors (CSFs) or interleukins (ILs) (2). These factors exert a multi- or unilineage stimulus; particularly, IL-3 and GM-CSF induce differentiation of pluripotent (CFU-GEMM), early E (BFU-E), and GM (CFU-GM) progenitors, whereas erythropoietin (Ep), G-CSF, and M-CSF specifically trigger differentiation of late erythroid (CFU-E), granulocytic (CFU-G), and monocytic (CFU-M) progenitors, respectively.

Coordinated expression of lineage-specific genes in developing hematopoietic cells is likely to be mediated in part by the programed activation/suppression and microenvironmentdirected expression of tissue- and stage-specific transcription factors. In this context, of prime transactivators are GATA-1, GATA-2, and NF-E2.

GATA-1, a 50-kD zinc finger protein, is expressed in mature erythroid cells, megakaryocytes, and mast cells (3-5), as well as in testis (6). GATA-1 regulates erythroid-expressed genes through core GATA motifs (5) and is required for normal erythroid development, as revealed by gene targeting in embryonic stem cells (7). Two mechanisms dependent on GATA-1 favor maturation of erythroid precursors: the GATA-1 gene is autoregulated through an upstream GATA element (8), and GATA1 positively regulates the Ep receptor $(E p R)$ promoter (9) and hence may forestall apoptosis due to Ep starvation (10).

GATA-1 expression has been evaluated in highly purified, early HPCs undergoing differentiation along the erythroid or granulocytic pathway (11). The GATA-1 gene, though barely expressed in quiescent HPCs, is activated after entrance into the cell cycle upon hematopoietic growth factor stimulus. Subsequently, increasing expression along the erythroid pathway

1. Abbreviations used in this paper: BFU, burst-forming unit; CSF, colony-stimulating factor; E, erythroid; Ep, erythropoietin, EpR, erythropoietin receptor; GM, granulocyte-monocytic; IMDM, Iscove's modified Dulbecco's medium; HPC, hematopoietic progenitor cell; HSC, hematopoietic stem cell; MK, megakaryocytic; RA, retinoic acid; RTPCR, reverse transcriptase PCR. 
contrasts with down-regulation in the granulocytic lineage (11). Recently, we have shown that retinoic acid (RA) induces HPCs to shift from the erythroid to the granulocytic differentiation pathway: this is coupled with and possibly mediated by suppression of GATA-1 expression (12).

GATA-2, a zinc finger protein binding GATA motifs (5), is expressed in both hematopoietic cells and other cell types (endothelial cells, fibroblasts, embryonic brain cells, and liver cells ) $(5,13,14)$. GATA-1 and -2 are coexpressed in mature mast and megakaryocytic cells $(3,4)$, whereas maturing erythroid cells contain abundant GATA-1 but little GATA-2 (11, 15). HPC-enriched populations express GATA-2 $(15,16)$.

The NF-E2 tissue-specific component (p45 NF-E2) is a basic region leucine zipper protein that dimerizes with a ubiquitous partner to form native NF-E2 (17). NF-E2 binds AP-1like recognition sites (17), which are required for in vivo activity of the locus-activating regions controlling expression of $\alpha$ and $\beta$-globin genes in developing erythroid cells (18), as well as for the promoter function of the erythroid-expressed porphobilinogen deaminase (19) and ferrochelatase genes (20).

We have investigated the expression and functional roles of GATA-1, GATA-2, and NF-E2 in purified human HPCs induced to unilineage erythroid or granulocytic differentiation. Their expression pattern was monitored at both the mRNA and protein levels by reverse transcriptase PCR (RT-PCR) and immunofluorescence, respectively. Their functional role was explored by two complementary approaches: HPC treatment with either antisense oligomer to knock out the transcription factor mRNA, or RA to induce a shift from erythroid to granulopoietic differentiation.

\section{Methods}

\section{Hematopoietic growth factors, chemical inducer, and cell medium}

Recombinant human IL-3 and GM-CSF ( 1.7 to $2.5 \times 10^{7} \mathrm{U} / \mathrm{mg}$ ) were supplied by Genetics Institute (Cambridge, MA), recombinant human Ep and c-kit ligand (KL) was from Amgen (Thousand Oaks, CA) and Immunex (Seattle, WA). G-CSF was obtained from R \& D System, Inc. (Minneapolis, MN). All trans-RA was purchased from Sigma Chemical Co. (St. Louis, MO). Iscove's modified Dulbecco's medium (IMDM; Gibco Laboratories, Grand Island, NY) was freshly prepared weekly.

\section{Adult peripheral blood}

Adult peripheral blood was obtained from $20-40$-yr-old healthy male donors after informed consent. $450 \mathrm{ml} \pm 10 \%$ of the blood was collected in preservative-free CPDA-1 anticoagulant (citrate-phosphate-dextrose-adenine). A buffy coat was obtained by centrifugation (J6M/E; Beckman Instrs., Fullerton, CA) at $1,400 \mathrm{rpm}$ for $20 \mathrm{~min}$ at room temperature.

\section{HPC purification}

Adult peripheral blood HPCs were purified according to a slight modification $(12,21,22)$ of the method previously reported (23). Briefly, the purification steps were as follows: (IA) peripheral blood samples were separated over a Ficoll-Hypaque density gradient $(d, 1.077)$; (Pharmacia Fine Chemicals, Piscataway, NJ). (IB) PBMCs resuspended in IMDM containing $20 \%$ heat-inactivated FCS (Gibco Laboratories) were treated with three cycles of plastic adherence. (II) Cells were separated by centrifugation on a discontinuous Percoll (Biochrom KG, Berlin, Germany), four-step gradient $(d, 1.052,1.056,1.060,1.065)$. Step III purification was potentiated (IIIP) as follows: low density cells (1.052 and 1.056 fractions) were collected and incubated with appropriate amounts of a cocktail of mAbs to T, B, and NK lymphocytes, monocytes, and granulocytes, as described (23), supplemented with three other mAbs (anti-CD45, -CD11a, and -CD71, Becton Dickinson, Mountain View, CA), which improve HPC recovery and purity $(12,21)$. Cells were then incubated with immunomagnetic monodisperse microspheres coated with sheep antibody to mouse Ig (Dynabeads M450, Dynal, Oslo, Norway) and separated with a magnet.

\section{HPC clonogenetic assay}

Purified HPCs were seeded $\left(1-1.5 \times 10^{2}\right.$ cells per ml per dish, two or three plates per point) and cultured in $0.9 \%$ methylcellulose, $40 \%$ FCS in IMDM supplemented with $\alpha$-thioglycerol $\left(10^{-4} \mathrm{M}\right.$ ) (Sigma Chemical Co.), and different growth factors, as will be detailed, at $37^{\circ} \mathrm{C}$ in a $5 \%$ $\mathrm{CO}_{2} / 5 \% \mathrm{O}_{2} / 90 \% \quad \mathrm{~N}_{2}$ humidified atmosphere. In $\mathrm{FCS}^{-}$cultures, FCS was substituted by (24) BSA $(10 \mathrm{mg} / \mathrm{ml})$, pure human transferrin (1 $\mathrm{mg} / \mathrm{ml})$, human LDLs $(40 \mu \mathrm{g} / \mathrm{ml})$, insulin $(10 \mu \mathrm{g} / \mathrm{ml})$, sodium pyruvate $\left(10^{-4} \mathrm{~mol} /\right.$ liter $)$, L-glutamine $\left(2 \times 10^{-3} \mathrm{~mol} /\right.$ liter $)$, rare inorganic elements (25) supplemented with iron sulphate $\left(4 \times 10^{-8} \mathrm{~mol} /\right.$ $1)$, and nucleosides $(10 \mu \mathrm{g} / \mathrm{ml}$ each $)$. Both $\mathrm{FCS}^{+}$and $\mathrm{FCS}^{-}$cultures were supplemented with KL (10 ng/ml), IL-3 (100 U), GM-CSF (10 ng), and Ep ( 3 U). CFU-GEMM, BFU-E, and CFU-GM colonies were scored on day 14 or days $16-18$ in $\mathrm{FCS}^{+}$or $\mathrm{FCS}^{-}$culture, respectively.

\section{HPC liquid suspension culture}

Step-IIIP HPCs were grown in liquid suspension culture $\left(5 \times 10^{4}\right.$ cells per $\mathrm{ml}$ of $\mathrm{FCS}^{-}$medium; see previous section) supplemented with hematopoietic growth factors (i.e., in granulocytic differentiation culture, low doses of IL-3 [1 U/ml], GM-CSF [0.1 ng/ml], and plateau level of G-CSF [ $500 \mathrm{U} / \mathrm{ml}]$; in erythroid differentiation culture, very low doses of IL-3 [0.01 U/ml] and GM-CSF $[0.001 \mathrm{ng} / \mathrm{ml}]$ and plateau level of Ep [ $3 \mathrm{U} / \mathrm{ml}])$. Cultures were incubated in a fully humidified atmosphere of $5 \% \mathrm{CO}_{2} / 5 \% \mathrm{O}_{2} / 90 \% \mathrm{~N}_{2}$ and were periodically counted, harvested, and analyzed for cell morphology and gene expression. (See reference 11 for details.)

\section{Morphology analysis}

Cells were harvested on different days, smeared on glass slides by cytospin centrifugation, and stained with May-Grünwald Giemsa.

\section{$R T-P C R$ analysis}

Total RNA, extracted by the guanidinium isothiocyanate/ $\mathrm{CsCl}$ method (26) from the same number of cells in the presence of $12 \mu \mathrm{g}$ of Escherichia coli rRNA carrier, was quantitated by dot hybridization with a human rRNA probe (11). After densitometric analysis, the normalized amount of RNA was reverse transcribed by Moloney murine leukemia virus reverse transcriptase (GIBCO BRL, Gaithersburg, MD) with oligo(dT) as primer. The RT-PCR was normalized for $\beta_{2}$-microglobulin (12): amplification within the linear range was achieved by 20 PCR cycles (denaturation at $95^{\circ} \mathrm{C}$ for $30 \mathrm{~s}$, annealing at $54^{\circ} \mathrm{C}$ for $30 \mathrm{~s}$, and extension at $72^{\circ} \mathrm{C}$ for $45 \mathrm{~s}$ ).

To evaluate the expression of the GATA-1, GATA-2, NF-E2, and EpR genes, an aliquot of RT-RNA ( $\sim 20 \mathrm{ng}$ ) was amplified within the linear range by 30 PCR cycles (i.e., the cycle number allowed a linear cDNA dose response). Each sample was electrophoresed in a $2 \%$ agarose gel, transferred to a nitrocellulose filter, and hybridized with an internal oligomer probe. An aliquot of RT-RNA ( $\sim 20 \mathrm{ng}$ ) from each sample and a mock reaction (negative controls) were amplified to exclude the presence of contaminant DNA. The sequences of primers and probes and the PCR conditions are as follows. Primers included 5'-TTAGCCACCTCATGCCTT-3' and 5'-GAGACTTGGGTTGTCCAG-3' for GATA-1 (12); 5'-TCCAGCTTCACCCCTAAGCAG-3' and 5'-GCATGCACTTTGACAGCTCC-3' for GATA-2 (14); 5'-ATGTCCATCACCGAGCTG-3' and 5'-CAATGTCCAGGAGGGCTA-3' for NF-E2 (27); 5'-GTATCATGGACCACCTCG-3' and 5'-CGGATGTGAGACGTCATG-3' for EpR (28). Internal probes included 5'-TACTGTGGTGGCTCCGCTCAGCTCATGAGGCACAGAGCA-3' for GATA-1; 5'-AAG- 

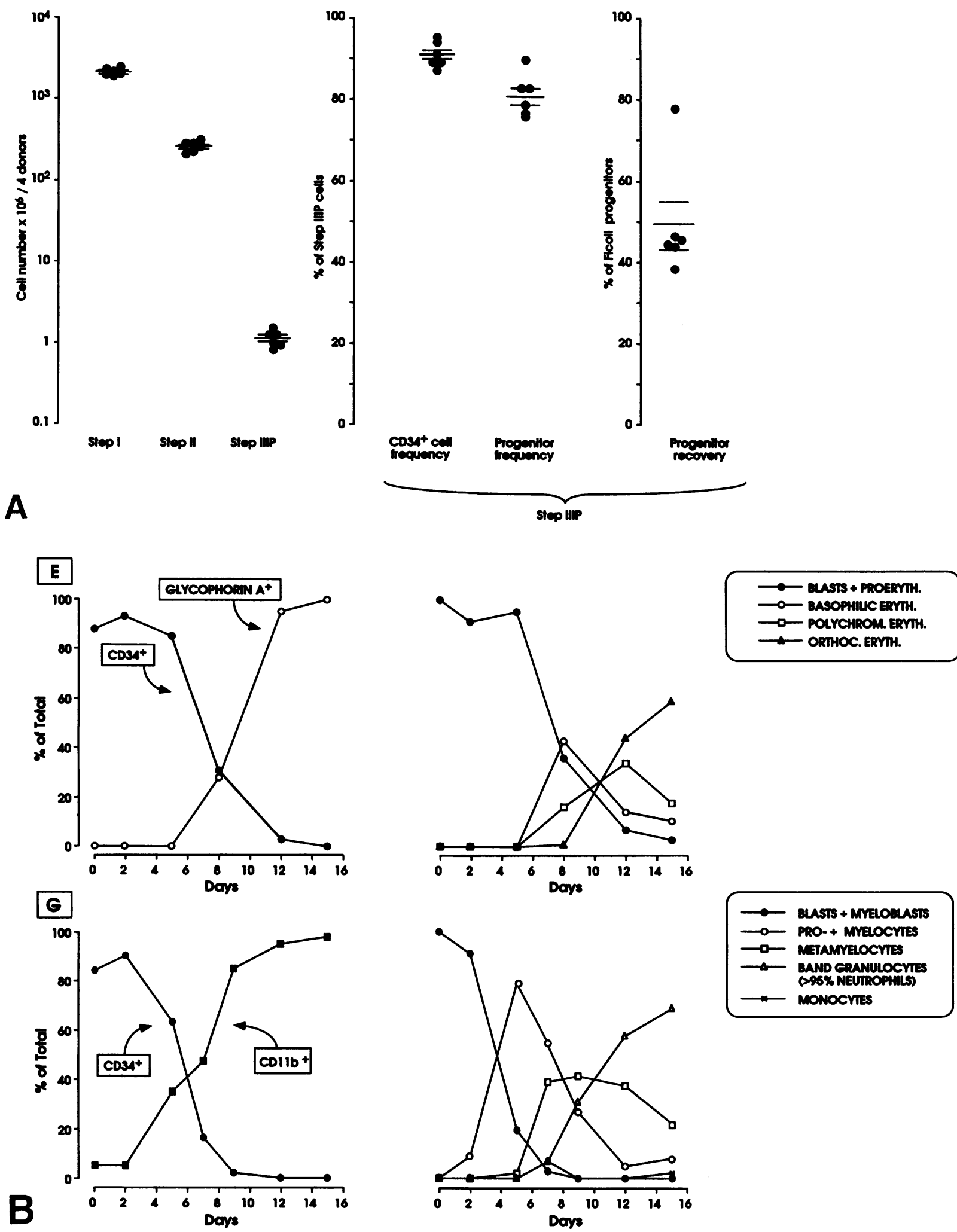

Figure 1. (A) Cell number, percentage of $\mathrm{CD} 34^{+}$cells, HPC frequency, and recovery in the step IIIP purification procedure (mean \pm SEM values from six separate experiments). (Left) Cell number was evaluated at different steps of purification, including Ficoll cut (step I), Percoll gradient (step II), and three sequential passages on magnetic beads (step IIIP). (Right) The percentage of CD34 ${ }^{+}$cells in step-III cells was evaluated by flow cytometry. Step-IIIP HPC (CFU-GEMM + BFU-E + CFU-GM) frequency and recovery were evaluated by clonogenetic assays in FCS ${ }^{+}$ conditions upon addition of saturating KL/IL-3/GM-CSF/Ep dosages. HPC recovery is expressed as a percentage of progenitor cells present after step IIIP as compared with their number in PBMCs (step I). (B) (Left) Gradual decline of CD34 ${ }^{+}$cells and appearance of lineage-specific markers (glycophorin A for the erythroid lineage and CD11b for the granulocytic series) on purified HPCs grown in erythroid ( $E$, top) or granulocytic $(G$, bottom) liquid phase culture system. (Right) Morphologic analysis of cells differentiating in erythroid (top) or granulopoietic (bottom) culture at the indicated days. A representative experiment is shown. 

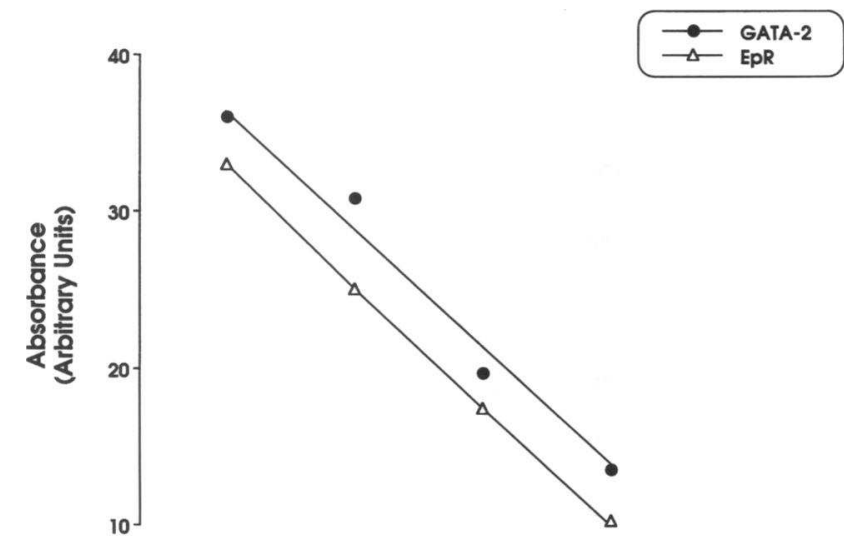

10
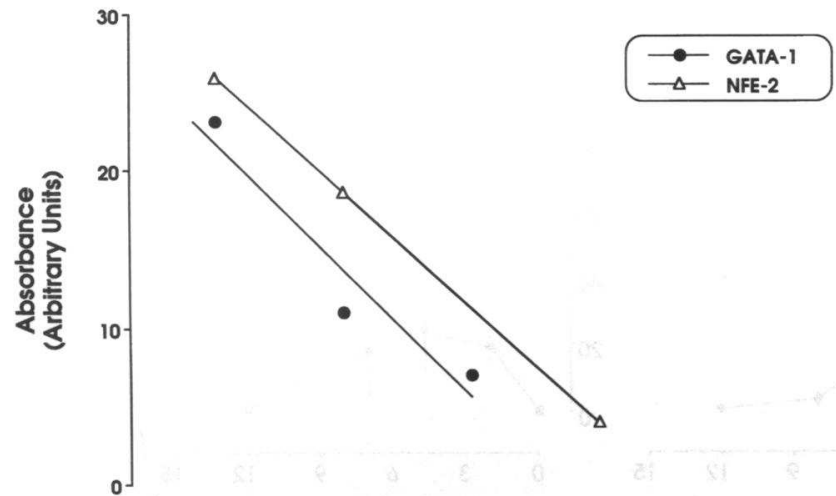

$\beta_{2} m$

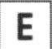

$\begin{array}{llllllllll}\text { Days } & 0 & 1 & 3 & 5 & 7 & 10 & 12 & 14 & K 562\end{array}$

GATA-2

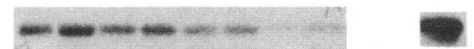

NF-E2

GATA-1

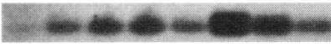

EpR
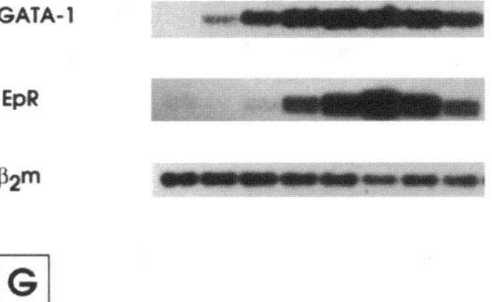

Days

$\begin{array}{lllllll}1 & 3 & 5 & 7 & 10 & 12 & 14\end{array}$

GAIA-2

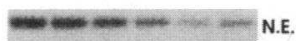

NF-E2

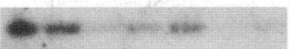

GATA-1

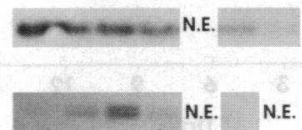

A

$1: 1$

$1: 3$

EpR

$B^{\mathrm{B}_{2} \mathrm{~m}}$

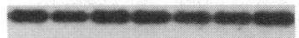

E Hours $\quad 0 \quad 3 \quad 6 \quad 24$

GATA-2

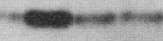

NF-E2

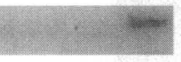

GATA-1

$\beta_{2} m$

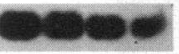

G

Hours

$\begin{array}{lll}3 & 6 & 24\end{array}$

GATA-2

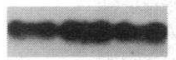

NF-E2

GAIA-1

Figure 2. (A) Representative dose-response curves for PCR of GATA-2, NF-E2, GATA-1, and EpR cDNA at different dilutions. The best fitting regression lines are indicated. ( $B$ and $C$ ) RT-PCR analysis of GATA-2, NF-E2, GATA-1, and EpR mRNA expression in step-IIIP HPCs induced to unilineage erythroid ( $E$, top) or granulopoietic $(G$, bottom) differentiation in liquid culture and analyzed at

C $\quad \beta_{2} m$ different culture times. $\beta_{2}$-microglobulin $\left(\beta_{2} m\right)$ was the internal control. The K562 cell line was used as a positive control. Representative results from three independent experiments are shown. 
A

E

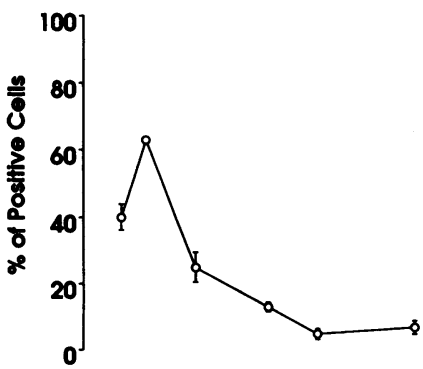

\section{(G)}

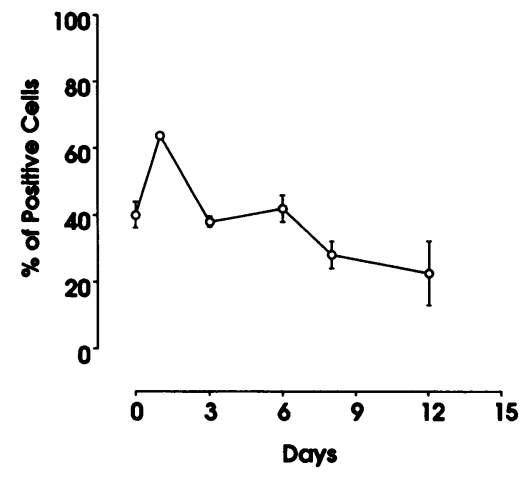

B

Day 0

Day 1
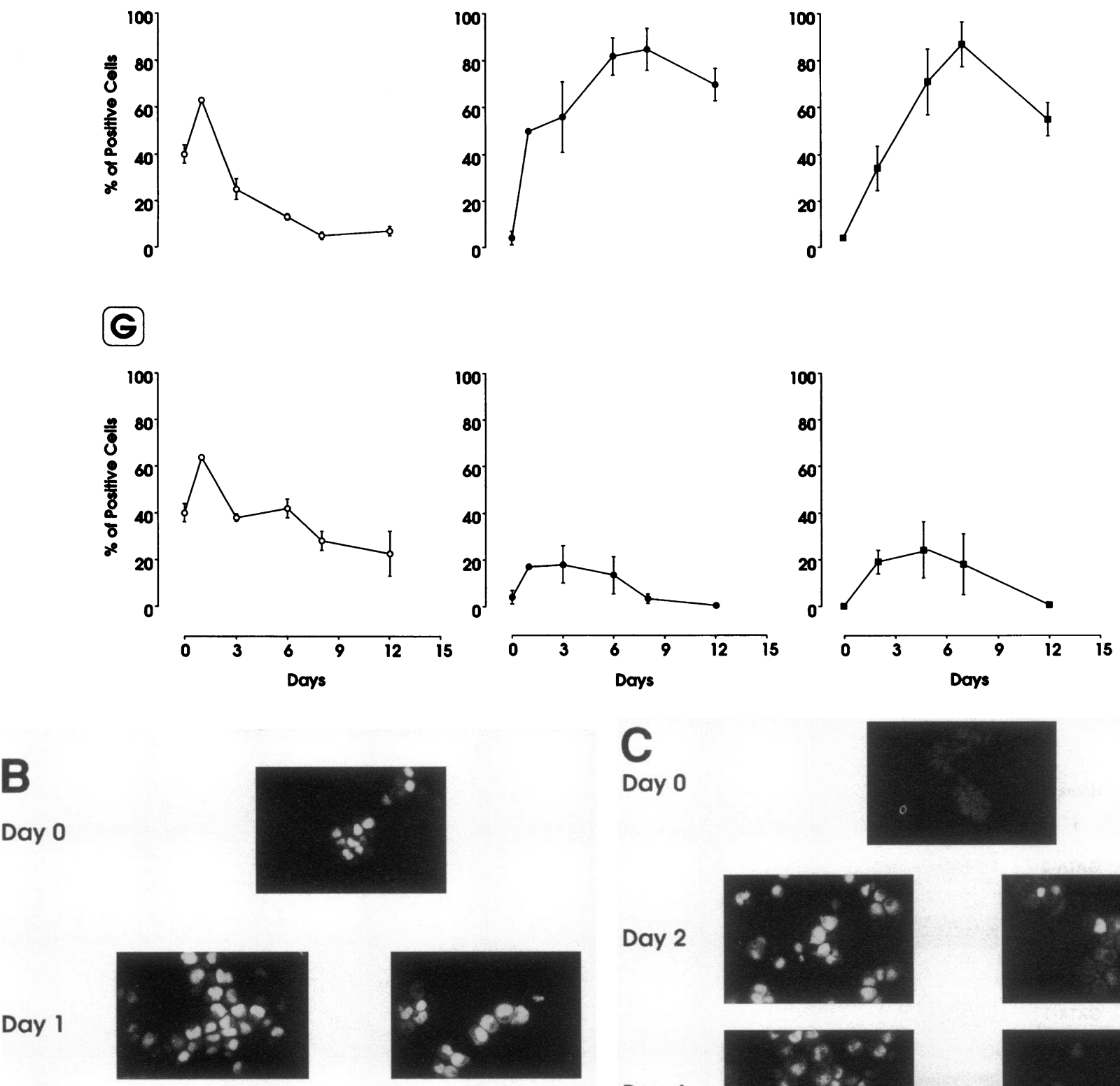

C

Day 0
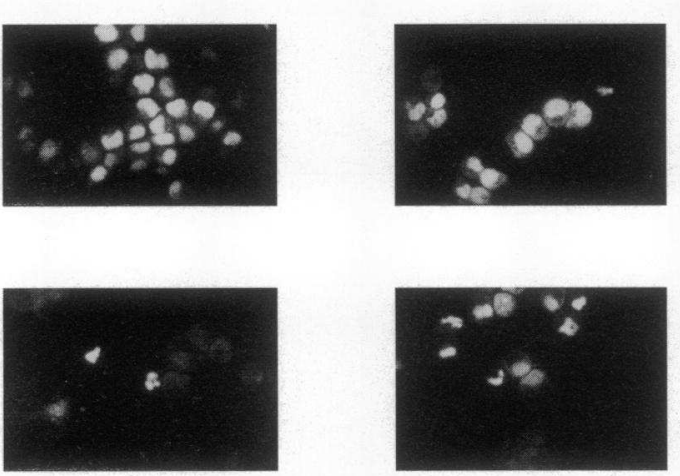

Day 2
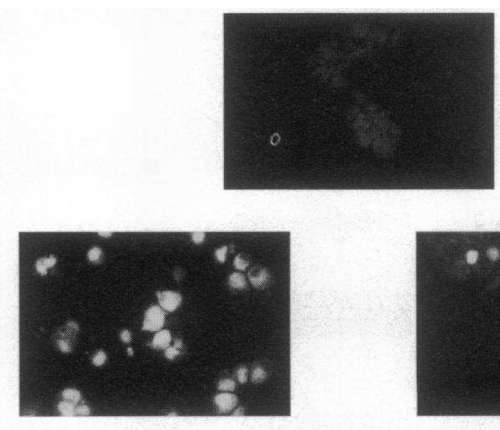

Day 6
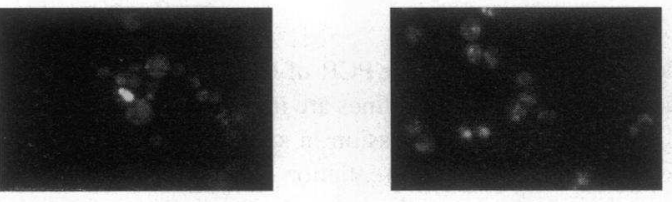

Day 12

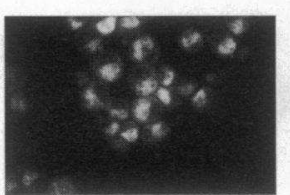

Day 8

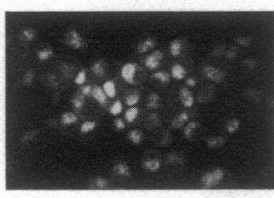

Day 12

E

G

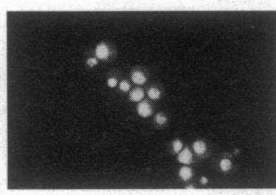

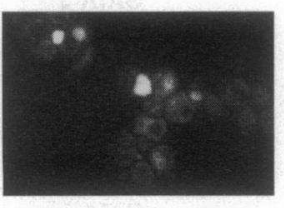
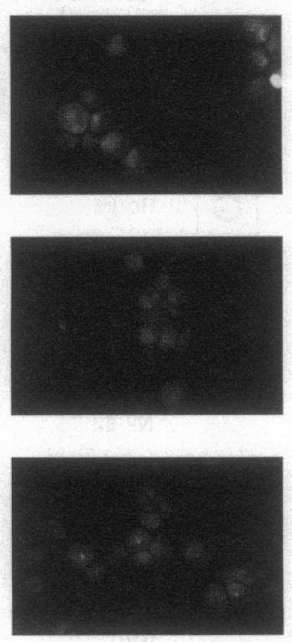

E 
D

Day 0
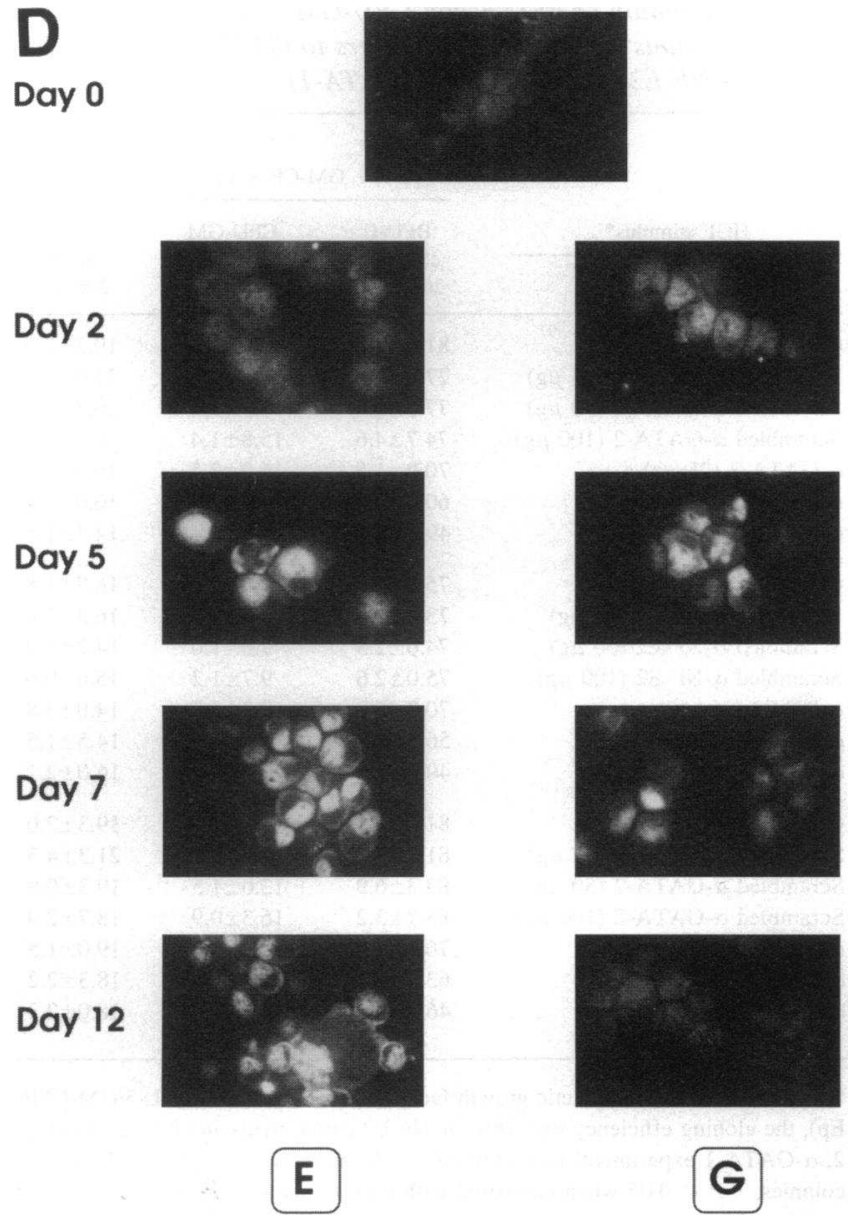

AGCCGGCACCTGTTTCAAATTGTCAGACG-3' for GATA-2; 5'CAATCCACCCAGATTCTGGCTTCCCAC- $3^{\prime}$ for NF-E2; 5'-AACTACAGCTTCTCCTACCAGCTCGAGGAT-3' for EpR. PCR conditions were $95^{\circ} \mathrm{C} / 30 \mathrm{~s}, 52^{\circ} \mathrm{C} / 30 \mathrm{~s}, 72^{\circ} \mathrm{C} / 45 \mathrm{~s}$ for GATA- $1 ; 95^{\circ} \mathrm{C} / 30 \mathrm{~s}$, $58^{\circ} \mathrm{C} / 30 \mathrm{~s}, 72^{\circ} \mathrm{C} / 45 \mathrm{~s}$ for GATA-2; $95^{\circ} \mathrm{C} / 30 \mathrm{~s}, 56^{\circ} \mathrm{C} / 30 \mathrm{~s}, 72^{\circ} \mathrm{C} / 45 \mathrm{~s}$ for NF-E2; $95^{\circ} \mathrm{C} / 30 \mathrm{~s}, 58^{\circ} \mathrm{C} / 30 \mathrm{~s}, 72^{\circ} \mathrm{C} / 45 \mathrm{~s}$ for EpR. In control experiments, serial dilutions of samples were amplified; the dose-response curves showed linearity for all points (see Results). Relative intensities of bands were quantified by scanning with a laser densitometer (PhosphorImager; Molecular Dynamics, Inc., Sunnyvale, CA).

\section{Immunofluorescence analysis}

The anti-GATA-1 mAb and polyclonal rabbit anti-human NF-E2 and GATA-2 antibodies were kindly provided by S. H. Orkin (Harvard Medical School, Boston, MA).

The cells were smeared on glass slides by cytospin centrifugation and then fixed for $5 \mathrm{~min}$ at room temperature with absolute methanol and for 2 min at $-20^{\circ} \mathrm{C}$ with acetone. After rehydration in PBS, the cells were incubated for $30 \mathrm{~min}$ at $37^{\circ} \mathrm{C}$ with a $1: 100$ dilution of anti-human GATA$1 \mathrm{mAb}$ and a 1:80 dilution of polyclonal anti-human NF-E2 and GATA2 antibodies. After extensive washing in PBS, the cells were then incubated for $30 \mathrm{~min}$ at room temperature with a 1:50 dilution of affinitypurified FITC-labeled sheep anti-mouse Igs. The slides were then extensively washed in PBS, mounted in PBS/glycerol, and observed under an epifluorescence microscope (Axiophot; Zeiss, Jena, Germany), using a $\times 63$ objective. Cells were photographed using a 400 ASA black and white film (TMAX; Eastman Kodak Co., Rochester, NY).

\section{HPC oligomer treatment and clonogenetic assay}

Antisense oligonucleotides. Phosphorothioate oligodeoxynucleotides were designed against the translational start region of the respective genes.
Figure 3. (A) Percentage of GATA-2 ${ }^{+}$, NF-E $2^{+}$, and GATA- ${ }^{+}$cells as determined by indirect immunofluorescence labeling and inspection of $\geq 500$ cells. Mean \pm SEM values from three to five separate experiments. $(B-D)$ Immunofluorescence labeling with anti-GATA-2 $(B)$, anti-NFE2 $(C)$ and anti-GATA-1 $(D)$ antibodies of HPCs differentiating in erythroid $(E)$ or granulopoietic $(G)$ culture. $(D)$ An exceptional megakaryocyte is present in day 12 erythroid culture. Fluorescent cells were examined under an Axiophot Zeiss microscope at $\times 630$. Representative results from three to five independent experiment are shown.

The scrambled sequence was derived by randomizing the antisense sequence. The sequences are as follows: GATA- 1 antisense ( $\alpha$-GATA-1), 5'-GAACTCCATGGAGCCTCT-3' (29); $\alpha$-GATA-1 scrambled, 5'CCTGACTGTGCACCGAAT- $3^{\prime} ; \alpha$-GATA-2, $5^{\prime}$-CAGCACGGCCGGGTGCGC-3' (14); $\alpha$-GATA-2 scrambled, 5'-GCACAGCGCCCGTGGCGG-3'; $\alpha$-NF-E2, $5^{\prime}$-GCAGCTCGGTGATGGACA-3' (26); $\alpha$-NF-E2 scrambled, 5'-GGAGAGCTTCACAGCGTG-3'.

Oligomer treatment. Step-IIIP cells were diluted in $\mathrm{FCS}^{-}$medium $\left(5 \times 10^{3}\right.$ cells per ml; medium composition as previously detailed) supplemented with hematopoietic growth factors (IL-3/GM-CSF/Ep; see clonogenetic assay previously described), in the presence or absence of antisense or randomly scrambled phosphorothioate oligomers at appropriate concentrations $(25,50$, and $100 \mu \mathrm{g} / \mathrm{ml})$ and incubated overnight. Cells were then plated in clonogenetic culture in triplicate dishes (see previous section). (See references 30 and 31 for more details.)

Oligomer uptake. Fluoresceinated oligomers were obtained from National Biosciences (Plymouth, MN). $5 \times 10^{3}$ step-IIIP HPCs were treated with $100 \mu \mathrm{g} / \mathrm{ml}$ scrambled or antisense oligomers overnight in $\mathrm{FCS}^{-}$culture with standard hematopoietic growth factors (IL3/GMCSF/Ep; see clonogenetic assay previously described). Cells were washed and analyzed by fluorescence-activated cell sorter.

\section{Results}

HPC purification and differentiation. HPCs were stringently purified from normal adult peripheral blood using a procedure (23) recently modified by a potentiated negative selection (step IIIP) to improve HPC recovery up to ' $50 \%(12,21$; see also Fig. $1 A$ ): in six separate purification experiments, the frequency 
of step-IIIP HPCs (CFU-GEMM + BFU-E + CFU-GM) was 81.0 \pm 2.0 in $\mathrm{FCS}^{+}$clonogenetic culture (Fig. $1 \mathrm{~A}$ ), with similar results in $\mathrm{FCS}^{-}$assay (data not shown).

The purified HPCs, triggered into cycling by hematopoietic growth factors in $\mathrm{FCS}^{-}$liquid suspension culture, undergo extensive proliferation coupled with a wave of gradual differentiation (see reference 11), which takes place selectively along the erythroid pathway (upon addition of very low IL-3 and GMCSF dosages combined with a saturating amount of Ep) or the granulopoietic pathway (upon treatment with small amounts of IL-3 and GM-CSF combined with saturating dosage of G-CSF) (representative results in Fig. $1 B$; see also reference 11 ). In the first week of culture, the HPCs showed high proliferative activity, as indicated by the cell growth curve ( see also reference 11). This level of activity was associated with their progressive differentiation, as shown by the gradual decrease in CD34 expression, blast number (Fig. $1 B$ ), and size of generated colonies (see reference 11). In the second week of culture, we observed the progressive expression of specific markers for differentiated erythroid or granulopoietic precursors (e.g., glycophorin A and CD11b, respectively) and the converse decline in the frequency of $\mathrm{CD}_{3} 4^{+}$cells to undetectable levels (Fig. $1 \mathrm{~B}$, left panels). Cell morphology analysis showed a gradual wave of maturation along the erythroid or granulopoietic pathway to terminal cells, i.e., $>97 \%$ mature erythroid cells with $>60 \%$ normoblasts in the erythroid culture and $98 \%$ mature granulocytic cells $(>60 \%$ neutrophilic granulocytes) in the granulopoietic system at day 17 (Fig. $1 \mathrm{~B}$, right panels). Contaminating monocytic cells were routinely $<5 \%$ (Fig. $1 B$ and data not shown).

$R T-P C R$ assay of GATA-2, NF-E2, GATA-1, and EpR mRNAs in differentiating step-IIIP HPCs. We have performed three independent experiments to evaluate the expression of GATA-2, NF-E2, GATA-1, and EpR mRNAs by RT-PCR in HPCs differentiating along the erythroid or granulopoietic pathway (representative results are shown in Fig. 2, $A-C$ ). A series of controls ensured a semiquantitative evaluation of mRNA levels (see Methods), including dose-response curves for the assayed templates (Fig. $2 \mathrm{~A}$ ).

GATA-2 mRNA, already expressed in the purified quiescent HPCs, was induced as early as $3 \mathrm{~h}$ after growth factor stimulus in both culture systems, peaked at days 1-5, and then gradually declined in advanced erythroid and granulocytic differentiation and maturation (Fig. 2, $B$ and $C$ ). NF-E2 and GATA-1 mRNAs, though barely or not detected in quiescent HPCs, were gradually induced at $\sim 24 \mathrm{~h}$ in both erythroid and granulopoietic cultures: starting with the late differentiation/early maturation stage, both transcription factors were sustainedly expressed in the erythroid pathway, whereas they were progressively suppressed in the granulopoietic series (Fig. 2, $B$ and $C$ ). EpR mRNA, which
Table 1. Inhibition of BFU-E and CFU-GM Colony Formation by Graded Amounts of Antisense Oligomers to GATA-2 ( $\alpha-G A T A-2)$, $N F-E 2(\alpha-N F-E 2)$, and GATA-1 ( $\alpha-G A T A-1)$

\begin{tabular}{|c|c|c|c|}
\hline \multirow[b]{2}{*}{ HGF stimulus* } & \multicolumn{2}{|c|}{$\mathrm{L}-3$ + GM-CF + Ep } & \multirow{3}{*}{$\begin{array}{c}\begin{array}{c}\mathrm{IL}-3+ \\
\text { GM-CSF }\end{array} \\
\begin{array}{l}\text { CFU-GM } \\
\text { colonies/ } \\
200 \text { cells }\end{array}\end{array}$} \\
\hline & \multirow{2}{*}{$\begin{array}{c}\text { BFU-E } \\
\text { colonies/ } \\
200 \text { cells }^{\ddagger}\end{array}$} & \multirow{2}{*}{$\begin{array}{l}\text { CFU-GM } \\
\text { colonies/ } \\
200 \text { cells }\end{array}$} & \\
\hline Colony type & & & \\
\hline Control & $81.0 \pm 3.1$ & $15.7 \pm 2.6$ & $19.3 \pm 2.0$ \\
\hline Scrambled $\alpha$-GATA-2 $(25 \mu \mathrm{g})$ & $77.0 \pm 3.0$ & $18.7 \pm 1.2$ & $21.0 \pm 3.6$ \\
\hline Scrambled $\alpha$-GATA-2 $(50 \mu \mathrm{g})$ & $77.7 \pm 3.2$ & $15.7 \pm 2.6$ & $20.3 \pm 1.4$ \\
\hline Scrambled $\alpha$-GATA-2 (100 $\mu \mathrm{g})$ & $74.7 \pm 4.6$ & $15.8 \pm 1.4$ & $20.3 \pm 1.4$ \\
\hline$\alpha$-GATA-2 (25 $\mu \mathrm{g})$ & $70.0 \pm 1.5$ & $16.0 \pm 2.5$ & $19.7 \pm 2.6$ \\
\hline$\alpha$-GATA-2 $(50 \mu \mathrm{g})$ & $60.3 \pm 2.9^{3}$ & $14.3 \pm 2.7$ & $16.0 \pm 2.1$ \\
\hline$\alpha$-GATA-2 $(100 \mu g)$ & $49.0 \pm 3.1^{11}$ & $11.4 \pm 0.7^{8}$ & $14.3 \pm 1.5^{\S}$ \\
\hline Control & $75.0 \pm 4.6$ & $10.7 \pm 1.3$ & $16.7 \pm 1.8$ \\
\hline Scrambled $\alpha$-NF-E2 $(25 \mu \mathrm{g})$ & $73.7 \pm 5.0$ & $8.3 \pm 0.7$ & $16.3 \pm 2.9$ \\
\hline Scrambled $\alpha$-NF-E2 $(50 \mu \mathrm{g})$ & $74.0 \pm 2.5$ & $9.0 \pm 1.0$ & $14.2 \pm 1.2$ \\
\hline Scrambled $\alpha$-NF-E2 $(100 \mu \mathrm{g})$ & $75.0 \pm 2.6$ & $9.7 \pm 1.2$ & $15.0 \pm 0.6$ \\
\hline$\alpha$-NF-E2 $(26 \mu g)$ & $70.7 \pm 5.3$ & $9.3 \pm 1.0$ & $14.0 \pm 3.8$ \\
\hline$\alpha$-NF-E2 $(50 \mu \mathrm{g})$ & $56.7 \pm 2.7^{11}$ & $8.7 \pm 0.9$ & $14.5 \pm 1.5$ \\
\hline$\alpha$-NF-E2 $(100 \mu \mathrm{g})$ & $40.7 \pm 2.0^{\prime \prime}$ & $9.7 \pm 0.9$ & $16.0 \pm 2.1$ \\
\hline Control & $81.0 \pm 3.1$ & $15.7 \pm 2.6$ & $19.3 \pm 2.0$ \\
\hline Scrambled $\alpha$-GATA-2 (25 $\mu \mathrm{g})$ & $81.7 \pm 2.4$ & $14.7 \pm 1.8$ & $21.3 \pm 4.3$ \\
\hline Scrambled $\alpha$-GATA-2 $(50 \mu \mathrm{g})$ & $83.3 \pm 6.9$ & $13.0 \pm 1.5$ & $19.3 \pm 0.9$ \\
\hline Scrambled $\alpha$-GATA-2 (100 $\mu \mathrm{g})$ & $83.7 \pm 3.2$ & $16.3 \pm 0.9$ & $18.7 \pm 2.9$ \\
\hline$\alpha$-GATA-1 (25 $\mu \mathrm{g})$ & $76.3 \pm 4.4$ & $15.0 \pm 1.7$ & $19.0 \pm 1.5$ \\
\hline$\alpha$-GATA-1 (50 $\mu \mathrm{g})$ & $63.0 \pm 1.2^{8}$ & $14.3 \pm 2.2$ & $18.3 \pm 2.2$ \\
\hline$\alpha$-GATA-1 $(100 \mu \mathrm{g})$ & $46.3 \pm 3.7^{11}$ & $15.0 \pm 1.5$ & $18.0 \pm 2.3$ \\
\hline
\end{tabular}

* Upon optimal hematopoietic growth factor (HGF) stimulus (KL/IL-3/GM-CSF/ Ep), the cloning efficiency was 76\% ( $\alpha$-NF-E2 experiment) and 83\% ( $\alpha$-GATA2, $\alpha$-GATA-1 experiment) (see Methods). ${ }^{\ddagger}$ Comprising a few CFU-GEMM colonies. " $P<0.05$ when compared with corresponding scrambled group. " $P$ $<0.01$ when compared with corresponding scrambled group.

was barely expressed in quiescent HPCs, was slowly induced in the erythropoietic pathway starting at day 5 , whereas it was barely or not expressed in the early or late stages of the granulopoietic pathway, respectively (Fig. $2 B$ ).

Expression of GATA-2, NF-E2, and GATA-1 proteins in differentiating HPCs as revealed by immunofluorescence analysis. In parallel, we monitored by indirect immunofluorescence the kinetics of GATA-2, NF-E2, and GATA-1 proteins in differentiating HPCs (Fig. 3, $A-D$ ). A significant proportion of quiescent HPCs displayed nuclear reactivity with anti-GATA-2 antibody; this reactivity apparently increased at day 1 in both erythroid and granulocytic differentiation systems but then progressively declined in the more advanced stages of differentiation/maturation (Fig. 3, $A$ and $B$ ). In contrast, NF-E2 and

Figure 4. $(A)$ Inhibition of BFU-E and CFU-GM colony formation upon treatment with an optimal concentration ( $100 \mu \mathrm{g} / \mathrm{ml})$ of antisense oligomer to GATA-2 ( $\alpha$-GATA-2), NF-E2 ( $\alpha$-NF-E2), and GATA-1 ( $\alpha$-GATA-1). (Top inserts) RT-PCR control of GATA-2, NF-E2, and GATA-1 mRNA expression: the decrease in NF-E2 mRNA upon $\alpha$-NF-E2 treatment was more pronounced in other experiments. (Middle and bottom) Number of BFU-E (comprising a few CFU-GEMM) and CFU-GM colonies after plating 200 step-IIIP HPCs in the absence or presence of antisense or scrambled oligomers with two different combinations of hematopoietic growth factors (IL-3, $10^{2} \mathrm{U} / \mathrm{ml}$; GM-CSF, $10 \mathrm{ng} / \mathrm{ml} ; \mathrm{Ep}, 3 \mathrm{U} / \mathrm{ml}$ [middle]; IL-3, $10^{2} \mathrm{U} / \mathrm{ml}$; GM-CSF, $10 \mathrm{ng} / \mathrm{ml}$ [bottom]). The optimal cloning efficiency in a control culture supplemented with saturating KL/IL-3/GMCSF/Ep dosages was $83 \%$ (see Methods). ${ }^{* * P}<0.02$ when compared with the corresponding scrambled group. Representative results in one of three independent experiments are presented. $(B)$ Effect of a low concentration $(25 \mu \mathrm{g} / \mathrm{ml})$ of $\alpha$-GATA-2 and $\alpha$-GATA-1, added alone or in combination, on colony formation by step-IIIP HPCs. See also $(A) .{ }^{*} P<0.01$ when compared with corresponding scrambled group. 

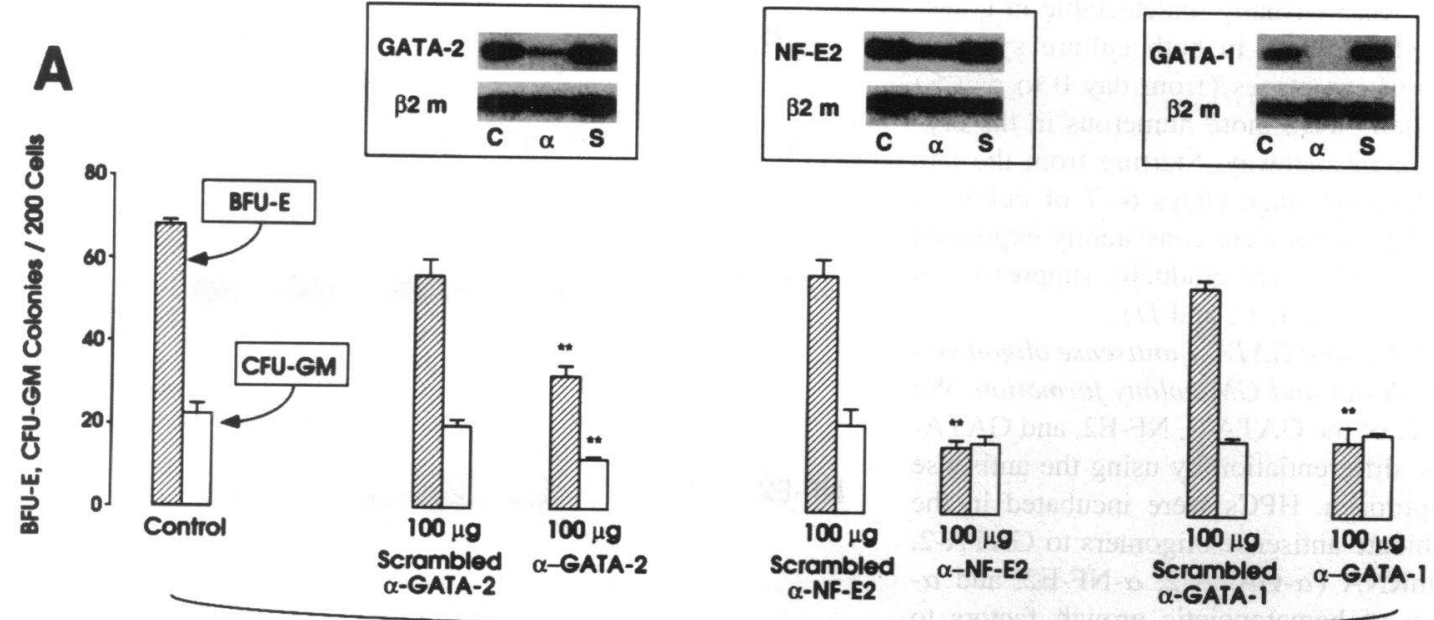

$\mathrm{Ep}+\mathrm{IL}-3$ + GM-CSF
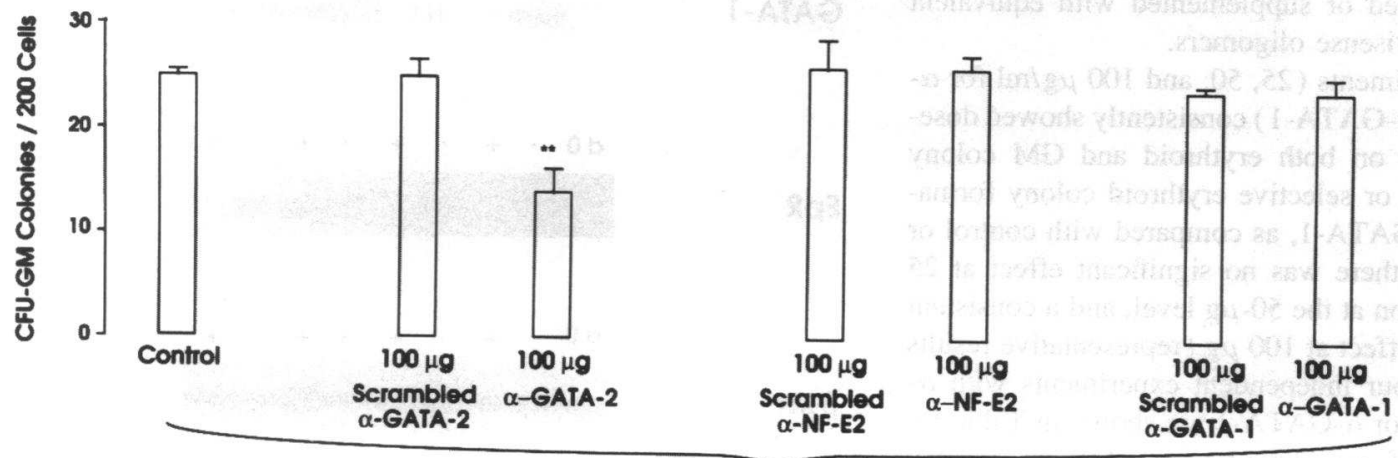

IL-3 + GM-CSF
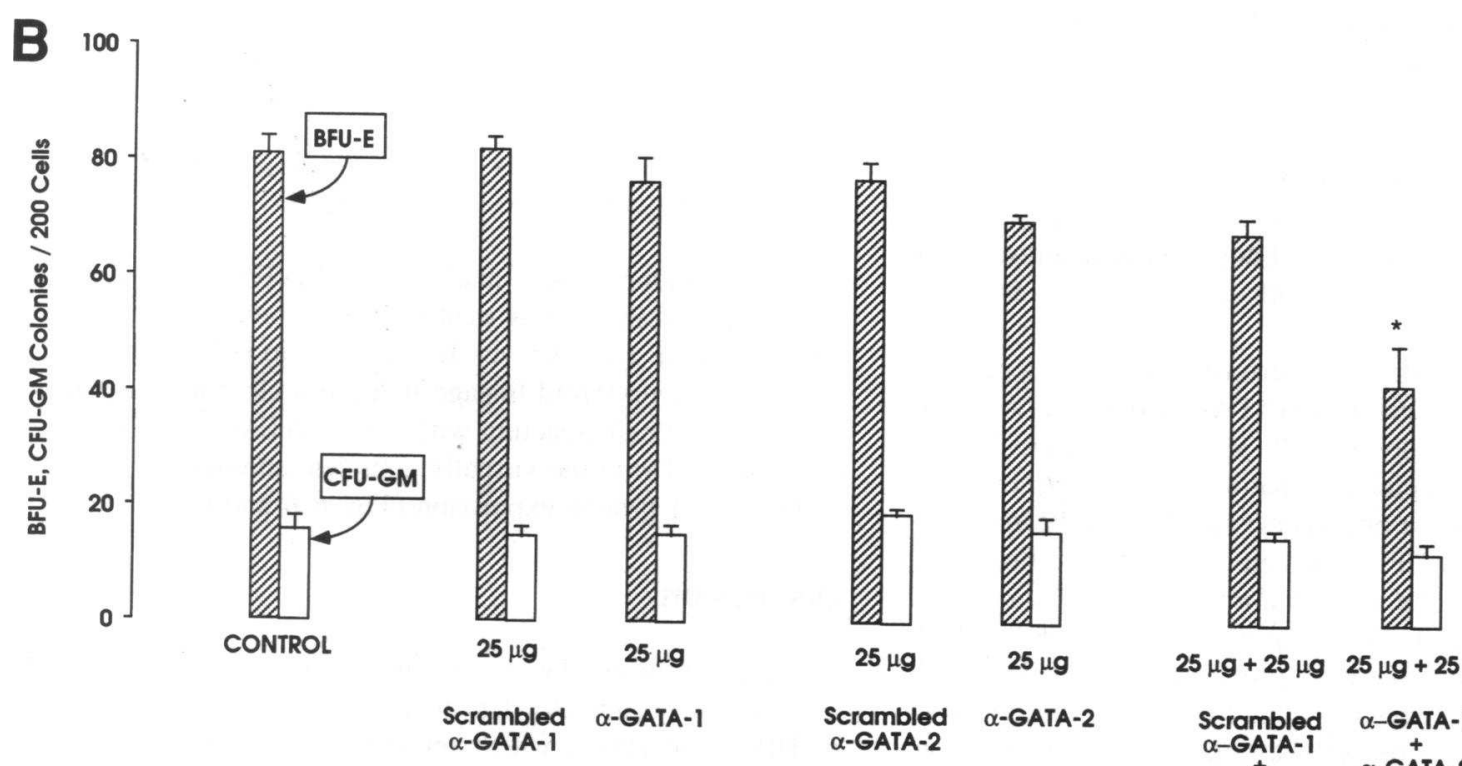

$25 \mu \mathrm{g}+25 \mu \mathrm{g} \quad 25 \mu \mathrm{g}+25 \mu \mathrm{g}$

Scrambled $\alpha-$ GATA-1

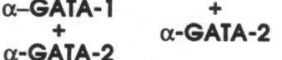

$$
\text { Ep + IL-3 + GM-CSF }
$$


GATA-1 proteins, which were virtually undetectable in quiescent HPCs, were induced at day 1 in both culture systems. During the early differentiation stages (from day 0 to day 5) NF-E2 ${ }^{+}$and GATA- ${ }^{+}$cells were more numerous in the erythroid than the granulopoietic pathway. Starting from the late differentiation/early maturation stage (days 6-7 of culture), both NF-E2 and GATA-1 proteins were consistently expressed in erythroid cells, whereas they were gradually suppressed in the granulopoietic series (Fig. 3, $A, C$, and $D$ ).

Effect of GATA-2, NF-E2, and GATA-1 antisense oligodeoxynucleotides on HPC erythroid and GM colony formation. We examined the possible role of the GATA-2, NF-E2, and GATA1 genes in hematopoietic differentiation by using the antisense oligodeoxynucleotide approach. HPCs were incubated in the presence of phosphorothioate antisense oligomers to GATA-2, NF-E2, and GATA-1 mRNA ( $\alpha$-GATA-2, $\alpha$-NF-E2, and $\alpha$ GATA-1) upon addition of hematopoietic growth factors to induce formation of erythroid and/or GM colonies. Control cultures were mock treated or supplemented with equivalent amounts of scrambled antisense oligomers.

Dose-response experiments (25, 50, and $100 \mu \mathrm{g} / \mathrm{ml}$ for $\alpha$ GATA-2, $\alpha$-NF-E2, and $\alpha$-GATA-1) consistently showed doserelated inhibitory effects on both erythroid and GM colony formation by $\alpha$-GATA- 2 or selective erythroid colony formation by $\alpha$-NF-E2 and $\alpha$-GATA-1, as compared with control or scrambled controls; i.e., there was no significant effect at 25 $\mu \mathrm{g}$, a mild inhibitory action at the $50-\mu \mathrm{g}$ level, and a consistent and marked suppressive effect at $100 \mu \mathrm{g}$ (representative results in one out of three or four independent experiments with $\alpha$ GATA-2, $\alpha$-NF-E2, and/or $\alpha$-GATA-1 are shown in Table I).

In a second series of experiments, we added in parallel $100 \mu \mathrm{g}$ of $\alpha$-GATA-2, $\alpha$-NF-E2, or $\alpha$-GATA-1 to the same population of step-IIIP HPCs (representative results in one out of three independent experiments are shown in Fig. $4 A$ ). Here again, a marked decrease of erythroid and GM colony number was induced by $\alpha$-GATA-2, whereas the inhibitory effect of $\alpha$ NF-E2 and $\alpha$-GATA-1 was restricted to the erythroid colonies. Additional control studies showed that each antisense oligomer induced marked or complete suppression of the target mRNA, but not of control $\beta_{2}$-microglobulin mRNA (Fig. 4, top insets). Furthermore, the 24-h uptake of fluoresceinated antisense or scrambled oligomers in target cells was always >90-95\% (data not shown).

Additional experiments were performed to verify a possible synergistic inhibitory effect of $\alpha$-GATA-2 and $\alpha$-GATA-1. The single addition of low dosage $(25 \mu \mathrm{g} / \mathrm{ml}) \alpha$-GATA-2 or $\alpha$ GATA-1 did not affect colony formation, whereas the combined addition of both antisense oligomers caused a significant reduction in BFU-E but not CFU-GM colony formation (Fig. $4 \mathrm{~B}$ ).

$R A$-induced erythroid to granulocytic differentiation shift: up-modulation of GATA-2 and suppression of NF-E2, GATA1, and EpR expression. We have previously shown that HPCs treated with RA are induced to shift from the erythroid to the granulocytic differentiation pathway; this phenomenon is coupled with abrogation of GATA-1 expression (12). Here we extend this analysis to the GATA-2 and NF-E2 and EpR genes.

As shown in Fig. 5 RA addition to HPCs triggered to differentiate along the erythroid lineage elicited an up-modulation of GATA-2 mRNA expression coupled with a pronounced decrease in NF-E2, GATA-1, and EpR mRNA levels. RA addition to HPCs induced to differentiate along the granulopoietic lin-

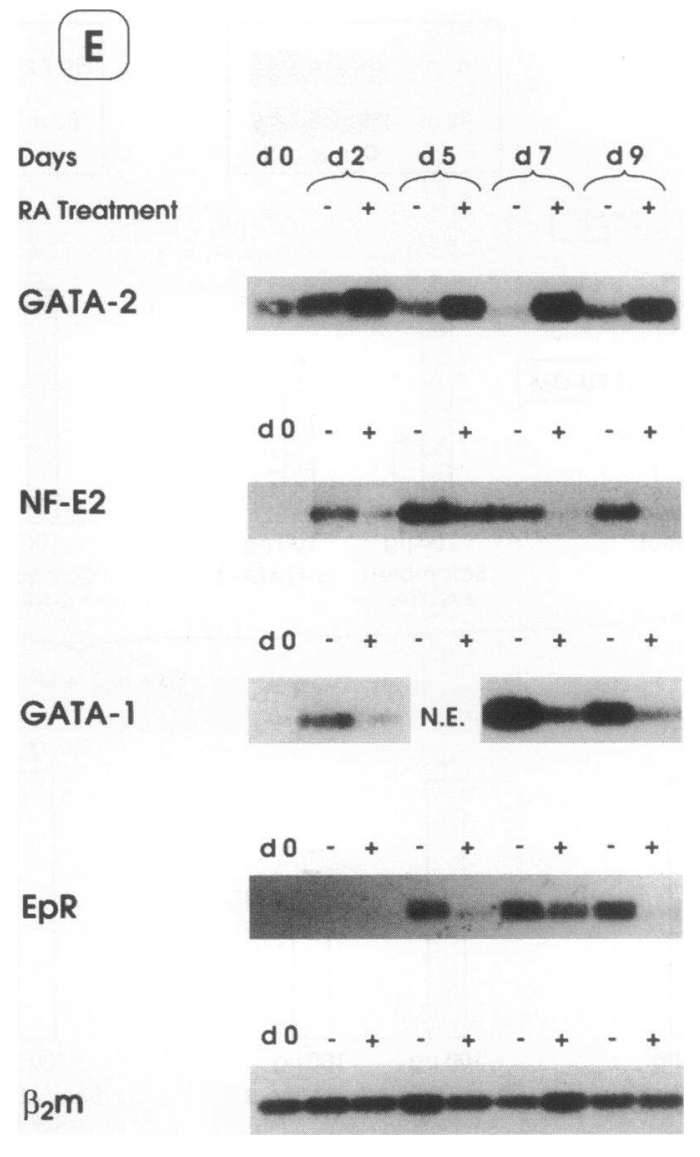

Figure 5. RT-PCR analysis of GATA-2, NF-E2, GATA-1, and EpR mRNAs expression in step-IIIP HPCs differentiating in the erythroid $(E)$ liquid phase culture in the absence or presence of RA $\left(10^{-6} \mathrm{M}\right)$. $\beta_{2}$-microglobulin $\left(\beta_{2} m\right)$ was the internal control. Representative results from three independent experiments are shown.

eage did not significantly modify the expression pattern of mRNAs encoding GATA-2, NF-E2, GATA-1, and EpR (data not shown).

Immunofluorescence analysis of GATA-2, NF-E2, and GATA-1 proteins in RA-treated HPCs confirmed the results obtained at the mRNA level. RA addition to HPCs differentiating along the erythroid lineage induced a clear increase in the percentage of cells reacting with anti-GATA-2 antibody (Fig. $6 A$ ) coupled with the virtually complete abrogation of NF-E2 and GATA-1 protein expression (Fig. $6 B$ and $C$ ).

\section{Discussion}

The discrete molecular events underlying early hematopoiesis are still poorly understood, primarily owing to the extreme rarity of HPCs and HSCs, which represent $<1 / 0.01 \%$ and $<0.1 /$ $0.001 \%$ of human bone marrow (32) and peripheral blood (33, 34 ) cells, respectively. Analysis of these events requires availability of sufficiently large and homogeneous populations of early hematopoietic cells at sequential stages of differentiation along the different lineages (21). Thus, it is necessary that early HPCs/HSCs be stringently purified and then cultured under rigorously controlled conditions to allow a gradual, homoge- 
A
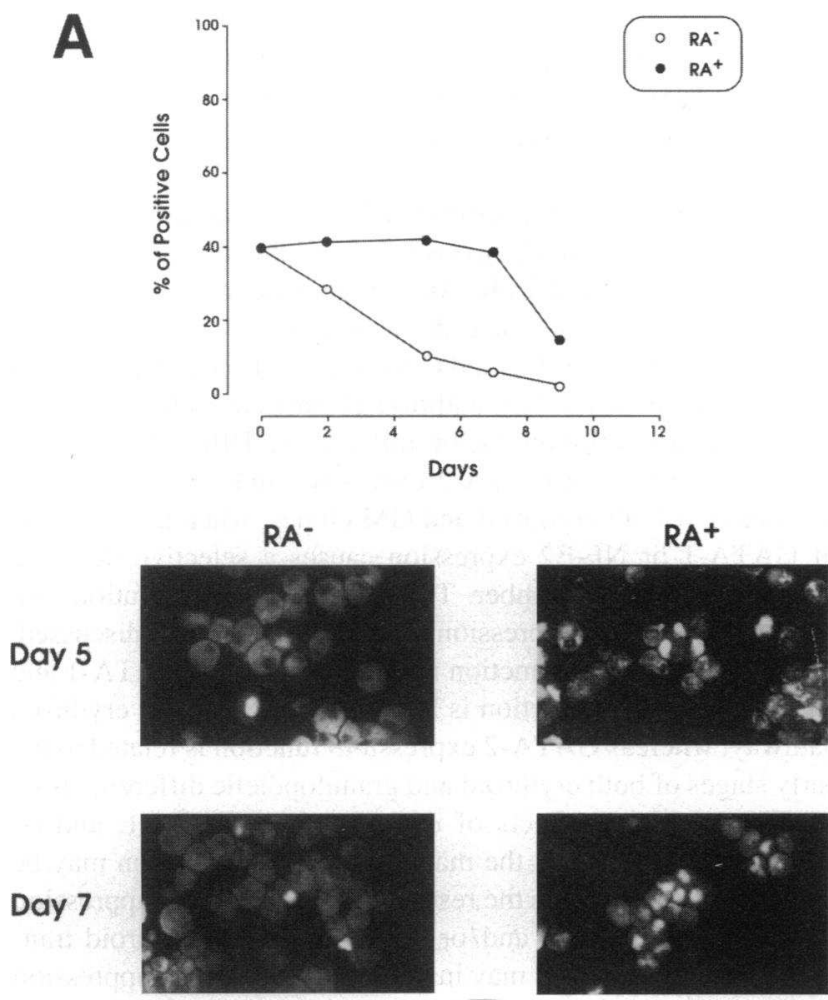

E

C

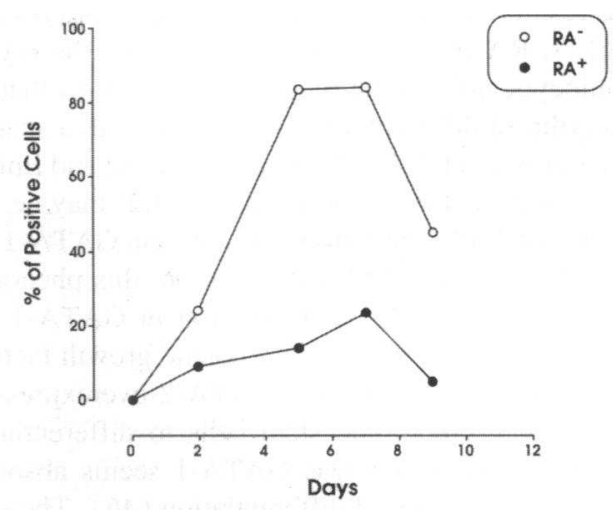

$\mathrm{RA}^{-}$

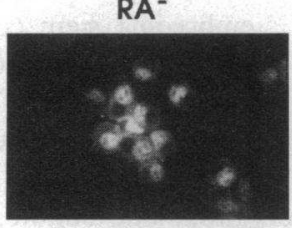

Day 7

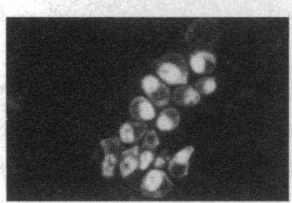

$\mathrm{RA}^{+}$
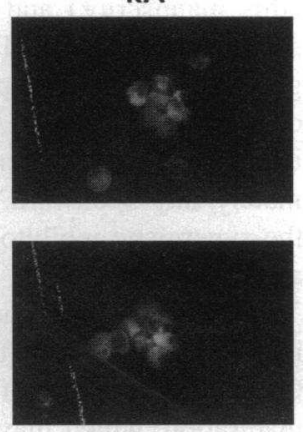

E
B

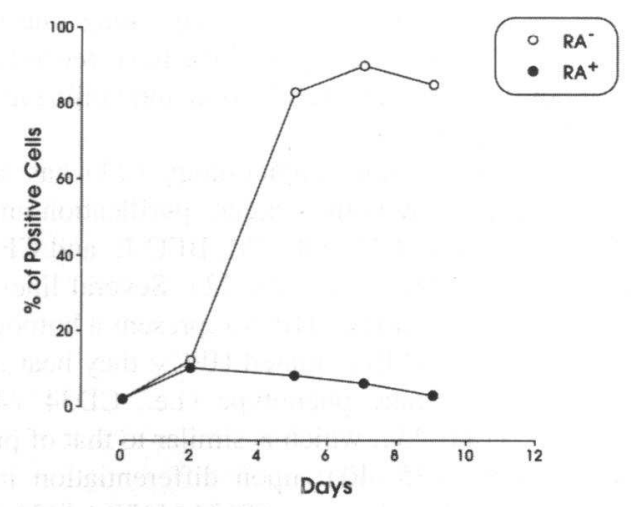

$\mathrm{RA}^{-}$

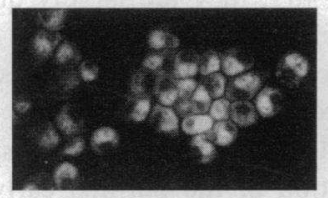

$\mathrm{RA}^{+}$

Day 5

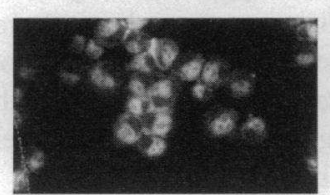

E

Day 7

)
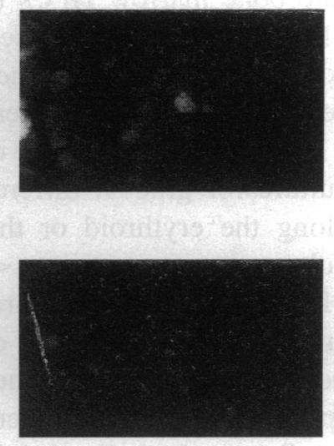

Figure 6. $(A-C)$ Immunofluorescence analysis of GATA-2 $(A)$, NF-E2 $(B)$, and GATA-1 $(C)$ expression in step-IIIP HPCs differentiating in the unilineage erythroid $(E)$ liquid culture system in the absence or presence of RA $\left(10^{-6} \mathrm{M}\right)$. (Top) Percentage of positive cells at different days of culture (representative results from three independent experiments); (bottom ) immunofluorescence labeling at days 5 and 7 of culture in the absence $\left(R A^{-}\right)$or presence $\left(R A^{+}\right)$of RA. 
neous wave of differentiation specifically along one or more lineage(s). In view of these aspects, we have recently developed a methodology for HPC purification and unilineage differentiation in liquid phase culture.

The original purification methodology (23) has been recently improved to allow both stringent purification and abundant recovery of HPCs (CFU-GEMM, BFU-E, and CFU-GM) from adult peripheral blood $(12,21,22)$. Several lines of evidence indicate that the purified HPCs represent a homogeneous population of highly undifferentiated HPCs: they bear a highly undifferentiated membrane phenotype (i.e., CD34 ${ }^{+} / 45 \mathrm{RA}^{-} /$

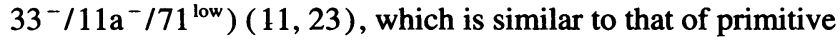
bone marrow HPCs (35-40); upon differentiation in liquid suspension culture, they become CD34 ${ }^{+} / 45 \mathrm{RA}^{+} / 33^{+} / 11 \mathrm{a}^{+} /$ $71^{\text {high }}(11,21)$, i.e., they acquire the phenotype of intermediate/ late bone marrow HPCs (35-40); they are largely quiescent ( $1-2 \%$ tritiated thymidine suicide index) and give rise to large colonies upon optimal hematopoietic growth factor stimulus (e.g., $10^{4}-10^{5}$ cells per erythroid burst) $(21,41)$.

Furthermore, we have developed an $\mathrm{FCS}^{-}$liquid suspension culture for gradual differentiation of the purified early HPCs along the erythroid or the granulopoietic lineage (the latter culture system comprises $<5 \%$ monocytes at late culture times ) $(11,21,41)$. These culture systems allow sequential collection and molecular analysis of discrete subsets of HPCs and hematopoietic precursors at a homogeneous stage of differentiation specifically along a particular lineage.

Our results indicate that the GATA-2, NF-E2, GATA-1, and EpR genes are differentially expressed during the early and late stages of hematopoietic differentiation.

Little is known about GATA-2 expression in early hematopoiesis, except for the detection of GATA-2 mRNA in partially purified HPCs $(15,16)$. Our study of stringently purified early HPCs differentiating in culture indicates that GATA-2 mRNA/ protein is present in a significant aliquot of quiescent HPCs, is further induced as early as $\mathbf{3 h}$ after hematopoietic growth factor stimulus and is expressed at gradually lower levels in erythroid and granulocytic differentiation and maturation. This pattern is consistent with the hypothesis that GATA-2 plays an important role in the earliest stages of HPC proliferation and differentiation.

The expression of NF-E2 in normal hematopoiesis has not been described. The present observations indicate that the NFE2 expression pattern is similar to that of GATA-1 and is characterized by little or no expression in quiescent HPCs; gradual induction after hematopoietic growth factor stimulus, starting at $\sim 24 \mathrm{~h}$; and sustained expression in the erythropoietic pathway and down-modulation in the granulopoietic series at the late progenitor/early precursor differentiation stage. This pattern is compatible with the hypothesis that, like GATA-1, NF-E2 plays an important role in erythroid differentiation and maturation.

We $(11)$ and others $(15,16)$ reported that GATA-1, which is barely present in early, quiescent HPCs, is preferentially expressed in the erythroid differentiation pathway. These observations are confirmed and extended by the immunofluorescence studies reported here.

EpR mRNA, which is barely expressed in quiescent HPCs, is gradually induced in the erythropoietic pathway, but not in granulopoietic differentiation. This pattern is in line with previous studies on EpR binding $(42,43)$ and is similar to that of NF-E2 and GATA-1. In erythropoietic differentiation, NF-E2 and GATA-1 induction precedes that of EpR: this temporal sequence is compatible with the hypothesis that the differentiative action of these transcription factors is directly and/or indirectly mediated via the EpR. Indeed, transfection studies indicate that GATA-1 positively regulates the EpR promoter (9, 44, 45).

Our studies do not discriminate between transcriptional and posttranscriptional mechanisms in the modulation of GATA-2, GATA-1, NF-E2, and EpR expression: additional experiments will be required to elucidate these aspects.

The GATA-2, NF-E2, and GATA-1 function in hematopoiesis has been evaluated by addition of antisense oligomers targeting the transcription factor mRNAs in HPC clonogenetic culture. Inhibition of GATA-2 expression induces an impaired formation of both erythroid and GM clones, whereas inhibition of GATA-1 or NF-E2 expression causes a selective decrease in erythroid colony number. These functional observations are coherent with the expression patterns previously discussed. Thus, the expression/function results indicate that GATA-1 and NF-E2 expression/function is largely restricted to the erythroid pathway, whereas GATA-2 expression/function is related to the early stages of both erythroid and granulopoietic differentiation.

The inhibitory effects of $\alpha$-GATA-2, $\alpha$-GATA-1, and $\alpha$ NF-E2 are only partial: the magnitude of the inhibition may be rendered less marked as the result of the incomplete suppression of the targeted mRNA and/or the rise of other erythroid transcription factors, which may in part compensate the suppression of the targeted mRNA and stimulate erythroid/GM differentiation (e.g., the rise of GATA-2 after GATA-1 suppression [46]; see the following discussion).

Interestingly, the antisense oligomer studies are consistent with the results obtained in the RA model. As previously reported (12), RA induces HPCs to shift from the erythroid to the granulocytic differentiation pathway. We show that suppression of erythroid differentiation is coupled with a sharp inhibition of not only GATA-1 (12), but also NF-E2 and EpR expression. This suggests that the RA-induced shift may be mediated by blockade of EpR expression, possibly via GATA-1 suppression. RA also induces GATA-2 elevation: this phenomenon is reminiscent of GATA-2 overexpression in GATA-1 - embryonic stem cells treated with erythropoietic growth factor stimulus (46). In this murine model, GATA-2 overexpression may allow GATA-1 - embryonic stem cells to differentiate to the proerythroblast stage, whereas GATA-1 seems absolutely required for further erythroid differentiation (46). The sharp rise in GATA-2 expression in both differentiating RA-treated HPCs (this manuscript) and GATA-1 ${ }^{-}$embryonic stem cells (46) suggests that GATA-1 exerts negative feedback on GATA-2 gene expression. This postulate is further supported by the concomitant decline in GATA-2 and rise in GATA-1 expression in the erythroid differentiation pathway, i.e., from approximately day 3 onward in HPC erythropoietic culture, and by the synergistic inhibitory effect of $\alpha$-GATA-2 and $\alpha$-GATA- 1 antisense oligomers.

Altogether, our studies indicate that GATA-2 plays a role in early HPC proliferation/differentiation, whereas NF-E2 and GATA-1 exert a key function in erythroid differentiation and maturation, which may be directly and/or indirectly mediated via the EpR. This postulate is also in line with the expression of GATA-2 in a variety of proliferating hematopoietic and nonhematopoietic cell types $(5,13,14)$, in contrast with the exclu- 
sive expression of NF-E2 (17-19) and GATA-1 (3-5) in hematopoietic and particularly erythropoietic cells (except for GATA-1 expression in testis [6]).

The present observations in human hematopoiesis correlate with studies in murine mutants. As previously mentioned, gene targeting studies in embryonic stem cells have shown that GATA-1 is essential for normal erythroid development (7): GATA-1 gene transfer into GATA ${ }^{-}$embryonic stem cells rescues erythroid development both in vivo and in vitro (47). Most recent studies on gene targeting of embryonic stem cells indicate that GATA-2 plays an important role in early hematopoietic proliferation (48). Finally, NF-E2 is required for globin expression in a murine erythroleukemic cell line in that reintroduction of $\mathrm{p} 45$ restores $\beta$-globin expression in NF-E2 ${ }^{-}$mutants (49).

We previously suggested a microenvironment-directed, twostep model for GATA-1 expression in differentiating HPCs that involves cycle-dependent initiation and lineage-dependent maintenance or suppression (11). Hypothetically, on/off switches of lineage-restricted transactivators may underlie the binary fate decisions of HPCs. The findings reported here suggest that this two-step model may also apply to NF-E2. Furthermore, the very rapid GATA-2 induction in HPCs treated with hematopoietic growth factors is seemingly related to activation of the cycling gene program and may in turn control the subsequent induction of lineage-specific transcription factors such as NF-E2 and GATA-1.

\section{Acknowledgments}

We thank Dr. S. H. Orkin for critical review of the manuscript and the generous gift of anti-GATA-1, -GATA-2, and -NF-E2 antibodies. We thank M. Fontana and C. Mastropietro for secretarial assistance and D. Marinelli for editorial assistance.

\section{References}

1. Metcalf, D. 1989. The molecular control of cell division, differentiation commitment and maturation in hematopoietic cells. Nature (Lond.). 339:27-30.

2. Ogawa, M. 1993. Differentiation and proliferation of hematopoietic stem cells. Blood. 81:2844-2853.

3. Martin, D. I. K., L. I. Zon, G. Mutter, and S. H. Orkin. 1990. Expression of an erythroid transcription factor in megakaryocytic and mast cell lineages Nature (Lond.). 344:444-446.

4. Romeo, P. H., M. H. Prandini, V. Joulin, V. Mignotte, M. Premont, W. Vainchenker, G. Marguerie, and G. Uzan. 1990. Megakaryocytic and erythrocytic lineages share specific transcription factors. Nature (Lond.). 344:447-469.

5. Orkin, S. H. 1992. GATA-binding transcription factors in hematopoietic cells. Blood. 80:575-581.

6. Ito, E., T. Toki, H. Ishihara, H. Ohtani, L. Gu, M. Yokoyama, J. D. Engel, and M. Yamamoto. 1993. Erythroid transcription factor GATA-1 is abundantly transcribed in mouse testis. Nature (Lond.). 362:466-468.

7. Pevny, L., M. C. Simon, E. Robertson, W. H. Klein, S. F. Tsai, V. D'Agati, S. H. Orkin, and F. Costantini. 1991. Erythroid differentiation in chimaeric mice blocked by a targeted mutation in the gene for transcription factor GATA-1. Nature (Lond.). 349:257-260.

8. Tsai, S.-F., E. Strauss, and S. H. Orkin. 1991. Functional analysis and in vivo footprinting implicate the erythroid transcription factor GATA-1 as a positive regulator of its own promoter. Genes Dev. 5:919-931.

9. Zon, L. I., H. Youssoufian, C. Mather, H. F. Lodish, and S. H. Orkin. 1991. Activation of the erythropoietin receptor promoter by transcription factor GATA1. Proc. Natl. Acad. Sci. USA. 88:10638-10641.

10. Koury, M. J., and M. C. Bondurant. 1990. Erythropoietin retards DNA breakdown and prevents programmed death in erythroid progenitor. Science (Wash DC). 248:378-381.

11. Sposi, N. M., L. I. Zon, A. Carè, M. Valtieri, U. Testa, M. Gabbianelli, G. Mariani, L. Bottero, C. Mather, S. H. Orkin, and C. Peschle. 1992. Cell cycledependent initiation and lineage-dependent abrogation of GATA-1 expression in pure differentiating hematopoietic progenitors. Proc. Natl. Acad. Sci. USA. 89:6353-6357.

12. Labbaye, C., M. Valtieri, U. Testa, A. Giampaolo, E. Meccia, P. Sterpetti, I. Parolini, E. Pelosi, D. Bulgarini, Y. E. Cayre, and C. Peschle. 1994. Retinoic acid downmodulates erythroid differentiation and GATA-1 expression in purified adult progenitor culture. Blood. 83:651-656.

13. Yamamoto, M., L. J. Ko, M. W. Leonard, H. Beug, S. H. Orkin, and J. D. Engel. 1990. Activity and tissue-specific expression in the transcription factor NF-E1 multigene family. Genes Dev. 4:1650-1662.

14. Lee, M.-E., D. H. Temize, J. A. Clifford, and T. Quertermous. 1991 Cloning of the GATA-binding protein that regulates endothelin-1 gene expression in endothelial cells. J. Biol. Chem. 266:16188-16192.

15. Leonard, M., M. Brice, J. D. Engel, and T. Papayannopoulou. 1993. Dynamics of GATA transcription factor expression during erythroid differentiation. Blood. 82:1071-1079.

16. Monton, M. A., O. Bernard, M. T. Mitjavila, P. H. Romeo, W. Vainchenker, and D. Mathien-Mahul. 1993. Expression of tal-1 and GATA-binding proteins during human hematopoiesis. Blood. 81:647-655.

17. Andrews, N. C., H. Erdjument-Bromage, M. B. Davidson, P. Tempst, and S. H. Orkin. 1993. Erythroid transcription factor NF-E2 is a haematopoieticspecific basic-leucine zipper protein. Nature (Lond.). 362:722-728.

18. Ney, P. A., B. P. Sorrentino, K. T. McDonagh, and A. W. Nienhuis. 1990. Tandem AP-1 binding sites within the human $\beta$-globin dominant control region function as an inducible enhancer in erythroid cells. Genes Dev. 4:993-1006

19. Mignotte, V., J. F. Elezouet, N. Raich, and P.-H. Romeo. 1989. Cis and trans-acting elements involved in the regulation of the erythroid promoter of the human porphobilinogen deaminase gene. Proc. Natl. Acad. Sci. USA. 86:65486552.

20. Taketani, S., J. Inazawa, Y. Nakahashi, T. Abe, and R. Tokunaga. 1992. Structure of the human ferrochelatase gene (exon/intron gene organization and location of the gene to chromosome 18). Eur. J. Biochem. 205:217-222.

21. Peschle, C., U. Testa, M. Valtieri, M. Gabbianelli, E. Pelosi, E. Montesoro, N. M. Sposi, C. Fossati, A. Camagna, and A. Carè. 1993. Stringently purified human hematopoietic progenitors/stem cells: analysis of cellular/molecular mechanisms underlying early hematopoiesis. Stem Cells. 11:356-370.

22. Giampaolo, A., P. Sterpetti, D. Bulgarini, P. Samoggia, E. Pelosi, M. Valtleri, and C. Peschle. 1994. Key functional role and lineage-specific expression of selected HOXB genes in purified hematopoietic progenitor differentiation. Blood. 84:3637-3647.

23. Gabbianelli, M., M. Sargiacomo, E. Pelosi, U. Testa, G. Isacchi, and C. Peschle. 1990. "Pure" human hematopoietic progenitors: permissive action of basic fibroblast growth factor. Science (Wash. DC). 249:1561-1564.

24. Valtieri, M., M. Gabbianelli, E. Pelosi, E. Bassano, S. Petti, G. Russo, U. Testa, and C. Peschle. 1989. Erythropoietin alone induces erythroid burst formation by human embryonic but not adult BFU-E in unicellular serum-free culture. Blood. 74:460-470.

25. Eliason, J. 1986. Granulocyte-macrophage colony-formation in serumfree culture: effects of purified colony-stimulating factors and modulation by hydrocortisone. J. Cell. Physiol. 128:231-238.

26. Chirgwin, M., A. E. Pezybyla, R. J. Mac Donald, and W. T. Rutter. 1979. Isolation of a biologically active ribonucleic acid from sources enriched in ribonuclease. Biochemistry. 18:5294-5299.

27. Chan, J. Y., X. L. Han, and Y. W. Kan. 1993. Isolation of cDNA encoding the human NF-E2 protein. Proc. Natl. Acad. Sci. USA. 90:11366-11370.

28. Jones, S. S., A. D. D'Andrea, L. L. Haines, and G. G. Wong. 1990. Human erythropoietin receptor: cloning, expression and biological characterization. Blood. 76:31-35.

29. Trainor, C. D., T. Evans, G. Felsenfeld, and M. S. Boguski. 1990. Structure and evaluation of a human erythroid transcription factor. Nature (Lond.). 343:9296.

30. Valtieri, M., D. Venturelli, A. Carè, C. Fossati, E. Pelosi, C. Labbaye, G. Mattia, A. M. Gerwitz, B. Calabretta, and C. Peschle. 1991. Antisense myb inhibition of purified erythroid progenitors in development and differentiation is linked to cycling activity and expression of DNA polymerase $\alpha$. Blood. 77:1181-1190.

31. Carè, A., U. Testa, A. Bassani, E. Tritarelli, E. Montesoro, P. Samoggia, L. Cianetti, and C. Peschle. 1994. Coordinate expression and proliferative role of HOX B genes in activated adult T lymphocytes. Mol. Cell. Biol. 14:4872-4877.

32. Müller-Sienburg, C., B. Torok-Storb, J. Visser, and E. Storb. 1992. Hematopoietic Stem Cells. Springer-Verlag, Heidelberg.

33. Udomsakdi, C., P. M. Lansdorp, D. E. Hogge, D. S. Reid, A. C. Eaves, and C. J. Eaves. 1992. Characterization of primitive hematopoietic cells in normal human peripheral blood. Blood. 80:2513-2521.

34. Valtieri, M., R. Schirò, C. Chelucci, U. Testa, I. Casella, E. Montesoro, H. J. Hassan, A. Biondi, and C. Peschle. 1994. Efficient gene transfer in human hematopoietic stem cells purified from peripheral blood and transduced in longterm culture. Cancer Res. 54:4398-4404.

35. Andrews, R. G., J. W. Singer, and I. D. Bernstein. 1989. Precursors of colony-forming cells in humans can be distinguished from colony-forming cells 
by expression of the $\mathrm{CD} 33$ and $\mathrm{CD} 34$ antigens and light scatter properties. $J$. Exp. Med. 169:1721-1731.

36. Lansdorp, P. M., H. J. Sutherland, and C. J. Eaves. 1990. Selective expression of CD45 isoforms on functional subpopulations of CD34 ${ }^{+}$hemopoietic cells from human bone marrow. J. Exp. Med. 172:367-373.

37. Leary, A. G., H. Q. Zeng, S. C. Clark, and M. Ogawa. 1992. Growth factor requirements for survival in $\mathrm{G}_{0}$ and entry into the cell cycle of primitive human hemopoietic progenitors. Proc. Natl. Acad. Sci. USA. 89:4013-4017.

38. Gunji, Y., M. Nakamura, T. Hagiwara, K. Hayakawa, H. Matsushita, H. Osawa, K. Nagayoshi, H. Nakauchi, M. Yanagisawa, Y. Miura, and T. Suda. 1992. Expression and function of adhesion molecules of human hematopoietic stem cells: CD34 ${ }^{+}$LFA-1 ${ }^{-}$cells are more primitive than CD $34^{+}$LFA-1 $^{+}$cells. Blood. 80:429-436.

39. Craig, W., R. Kay, R. L. Cutler, and P. M. Lansdorp. 1993. Expression of Thy-1 on human hematopoietic progenitor cells. J. Exp. Med. 177:1331-1342.

40. Fritsch, G., P. Buchinger, D. Printz, F. M. Fink, G. Mann, C. Peters, T. Wagner, A. Adler, and H. Gadner. 1993. Rapid discrimination of early CD34 ${ }^{+}$ myeloid progenitors using CD45-RA analysis. Blood. 81:2301-2309.

41. Peschle, C., M. Gabbianelli, U. Testa, E. Pelosi, T. Barberi, C. Fossati, M. Valtieri, and L. Leone. 1993. $c$-kit ligand reactivates fetal hemoglobin synthesis in serum-free cultures of stringently purified normal adult burst-forming uniterythroid. Blood. 81:328-336.

42. Sawada, K., S. B. Krantz, C. H. Dai, S. T. Koury, S. T. Horn, A. D. Glick and C. I. Civin. 1990. Purification of human blood burst-forming units-erythroid and demonstration of the evolution of erythropoietin receptors. J. Cell. Physiol. 142:219-228.

43. Testa, U., E. Pelosi, M. Gabbianelli, C. Fossati, S. Campisi, G. Isacchi, and C. Peschle. 1993. Cascade transactivation of growth factor receptors in early human hematopoiesis. Blood. 81:1442-1456.

44. Chiba, T., P. Ikawa, and K. Tohokoro. 1991. GATA-1 transactivates erythropoietin receptor gene, and erythropoietin receptor-mediated signal enhance GATA-1 gene expression. Nucleic Acids Res. 19:3843-3848.

45. Haberlein, C., K. D. Fisher, M. Stoffel, J. Nowock, A. Ford, U. Tessmer, and C. Stocking. 1992. The gene for erythropoietin receptor is expressed in multipotential hemopoietic and embryonal stem cells: evidence for differentiation stage-specific regulation. Mol. Cell. Biol. 12:1815-1825.

46. Weiss, M. J., G. Keller, and S. H. Orkin. 1994. Novel insights into erythroid development revealed through in vitro differentiation of GATA-1 - embryonic stem cells. Genes Dev. 8:1184-1197.

47. Simon, M. C., L. Pevny, M. V. Wiles, G. Keller, F. Costantini, and S. H. Orkin. 1992. Rescue of erythroid development in gene targeted GATA-1 ${ }^{-}$mouse embryonic stem cells. Nature Genet. 1:92-98.

48. Tsai, F.-Y., G. Keller, F. C. Kuo, M. Weiss, J. Chen, M. Rosenblatt, F. W. Alt, and S. H. Orkin. 1994. An early hematopoietic defect in mice lacking the transcription factor GATA-2. Nature (Lond.). 371:221-226.

49. Lu, S.-J., S. Rowan, M. R. Bani, and Y. Ben-David. 1994. Retroviral integration within the Flin-2 locus results in inactivation of the erythroid transcription factor NF-E2 in Friend erythroleukemias: evidence that NF-E2 is essentia for globin expression. Proc. Natl. Acad. Sci. USA. In press. 